\title{
Teratogenic Effect of Ethylene Glycol-Methyl Cellosolve Mixture in Rats. I. Reproductive Damage
}

\author{
Teratogénesis por Etilenglicol-Metilcelosolve en Ratas. I. Daño Reproductivo
}

${ }^{*, * *}$ Manuel Arteaga-Martínez; *,**Isabel García-Peláez; ${ }^{* * *}$ Oswaldo M. Aguirre-Luna \& ***Dolores Saavedra-Ontiveros

ARTEAGA-MARTíNEZ, M.; GARCÍA-PELÁEZ, I.; AGUIRRE-LUNA, O. M. \& SAAVEDRA-ONTIVEROS, D. Teratogenic

effect of ethylene glycol-methyl cellosolve mixture in rats. I. Reproductive damage. Int. J. Morphol., 28(4):1087-1092, 2010.

SUMMARY: We investigated the reproductive damage and teratogenic effect of an ethylene glycol-methyl cellosolve mixture on gestating Wistar rats, which received a daily intraperitoneal dose of different concentration of the mixture on day 8 of gestation until day 20. In rats treated with the mixture the number of live fetuses decreased and reabsorptions increased with increasing concentrations of the mixture, as well as the number of abnormal fetuses. We conclude that the ethylene glycol-methyl cellosolve mixture possesses a higher teratogenic potential than each of its constituents separately, producing reproductive damage, external fetal abnormalities, growth delay, and increased fetal death.

KEY WORDS: Ethylene glycol; Glycol ethers; Methyl cellosolve; Rat fetuses; Teratogenesis.

\section{INTRODUCTION}

Each day mankind has to face a larger number of potentially health-noxious agents; among them, chemicals used in industries occupy a preponderant place. These compounds, besides contaminating the environment, can affect importantly workers involved in their production and/ or those using these substances. If pregnant women are among these workers, their children can be affected when the maternal environment is affected and, even, the embryo's micro environment when these substances cross the placental barrier, turning these substances into teratogenic agents. In 1992, a group of 44 patients between 16 and 19 years of age, affected physically and mentally at birth, was identified in the city of Matamoros, Tamaulipas, Mexico, all had as common antecedent that their mothers were workers at an assembly plant, having been in direct contact with a mixture of different industrial solvents during gestation, without appropriate protection. This gave rise to the establishment of a new teratogenic syndrome, not described previously, originated by prenatal exposure to industrial solvents; epidemiological and clinical studies pointed towards ethylene glycol $\left(\mathrm{HO}-\mathrm{CH}_{2}-\right.$ $\left.\mathrm{CH}_{2}-\mathrm{OH}\right)$ and methyl cellosolve $\left(\mathrm{HO}-\mathrm{CH}_{2}-\mathrm{CH}_{2}-\mathrm{O}-\mathrm{CH}_{3}\right)$ as the possible responsible agents, both of the group of the so-called "glycol ethers" (Saavedra-Ontiveros et al., 1996; Saavedra et al., 1997). We performed an experimental study in rats, confirming the teratogenic action of both solvents when applied independently, and found morphological alterations more or less similar to those observed in the patients (Saavedra-Ontiveros et al.; Saavedra et al., 1997), as well as microscopic alterations of the central nervous system compatible with the functional alterations observed in the patients (Saavedra et al., 1998).

Ethylene glycol and methyl cellosolve (also called 2-methoxyethanol) are two of the most commonly used solvents in industry and in household products during the last decades; hence, a large population is exposed to their action (Smith, 1984; Cordier et al., 1997; Johanson, 2000; Anderson, 2005). It is well known their toxic effects and

\footnotetext{
Facultad de Medicina de la Universidad Nacional Autónoma de México. México, D.F.

** Escuela de Medicina de la Universidad Panamericana, México, D.F.

**** Hospital Infantil de México "Federico Gómez", México, D.F.

Research performed at Hospital Infantil de México "Federico Gómez" and Department of Anatomy, Facultad de Medicina UNAM. México, D.F., México.
} 
median lethal dose (LD50), their capacity to be absorbed through the skin and mucous membrane are well known (Cook et al., 1982; Nelson et al., 1989; Horton et al., 1985; Vachhrajani \& Dutta, 1992; Dieter, 1993; Oudiz et al., 1993; Terry et al., 1994; El-Zein et al., 2002), as well as the higher risk of abortions in exposed mothers and congenital malformations in their off-springs (Pastides et al., 1988; Bolt \& Golka, 1990; Swan et al., 1995; Saavedra-Ontiveros et al.; Saavedra et al., 1997, Saavedra et al., 1998; Johanson; Karaman et al., 2002), although their teratogenic effect has been minimized and even omitted in some investigations.

Although, the independent teratogenic effect of ethylene glycol and methyl cellosolve in the rat was fully demonstrated in our previous works, the epidemiological study of the patients affected in the city of Matamoros, Mexico suggests the combined action of these chemicals, since the mothers of the patients were in contact with a mixture of both (Saavedra-Ontiveros et al.; Saavedra et al., 1997; Saavedra et al., 1998). In addition, not all the alterations found in the rat fetuses were observed in the patients, neither were all the features of the patients found in the fetuses of the exposed rats, which could be due to a species-specific effect, or that the combination of both substances induces a different effect from that induced when exposed to each separately. Based on these findings, we considered it relevant to investigate the reproductive damage induced by the combination of both solvents in gestating rats; we chose intraperitoneal injection as the most efficient way of assessing the possible effects. In this first part of our research, the reproductive damage is reported, and in the next papers we will report the abnormal external morphological findings of the fetuses and their thoraco-abdominal viscera alterations of the same specimens.

\section{MATERIAL AND METHOD}

An experimental blind and transverse study was performed in 35 pregnant Wistar rats, maintained under standard conditions in the general bioterium of the "Federico Gómez" Children's Hospital of Mexico City. The rats were randomly divided in three main groups: Group A or control group $(\mathrm{n}=5)$, those not receiving any substance, but maintained under the same conditions as the other groups. Group B or saline solution group $(n=5)$, those that were injected intraperitoneally a daily dose of $0.5 \mathrm{ml}$ saline solution at days 8 to 20 of gestation. Group $\mathrm{C}$ or a mixture of ethylene glycol-methyl cellosolve in saline solution $(\mathrm{n}=$ $25)$, those that were injected intraperitoneally a daily dose of $0.5 \mathrm{ml}$ of this mixture at different concentrations, and divided into five subgroups:
Subgroup $\mathrm{C}_{1}$. Ethylene glycol-methyl cellosolve solution at $1.25 \%(\mathrm{n}=5)$

Subgroup $\mathrm{C}_{2}$. Ethylene glycol-methyl cellosolve solution at $2.5 \%(\mathrm{n}=5)$

Subgroup $\mathrm{C}_{3}$. Ethylene glycol-methyl cellosolve solution at $5 \%(\mathrm{n}=5)$

Subgroup $\mathrm{C}_{4}$. Ethylene glycol-methyl cellosolve solution at $10 \%(\mathrm{n}=5)$

Subgroup $\mathrm{C}_{5}$. Ethylene glycol-methyl cellosolve solution at $20 \%(\mathrm{n}=5)$

When the rats reached the $21^{\text {st }}$ day of gestation they were anesthetized by ether inhalation and the fetuses were obtained by cesarean section; once the fetuses had been obtained, the mothers were killed by applying a lethal anesthetic dose. The number of alive, dead fetuses, and reabsorptions of each one of the litters was registered. The fetuses were fixed by immersion in $5 \%$ formalin buffer during 72 hours, and subjected to qualitative and quantitative analyses.

In each case the uterine horns were observed under a Nikon SMZ-10 stereoscopic binocular microscope with the purpose of precise number of the reabsorptions and characteristics of the dead fetuses.

\section{RESULTS}

In group A (control), 61 conceptus were obtained from the five litters; of these, 44 were live fetuses $(72.1 \%)$ and 17 reabsorptions $(27.9 \%)$, with an average of 8.8 live fetuses and 3.4 reabsoptions per litter (Table I). The external morphological characteristics of all the live fetuses of this group were normal (Fig. 1A).

In group B (saline solution), 63 conceptus were obtained from the five litters; of these, 50 corresponded to live fetuses $(79.4 \%)$, three to dead fetuses $(4.8 \%)$, and 10 to reabsorptions $(15.9 \%)$, with an average of 10 live fetuses and 2.6 dead fetuses/reabsorptions per litter (Table I). The external morphological characteristics of all the live and dead fetuses of this group were normal.

In subgroup $\mathrm{C}_{1}$ (solution at $1.25 \%$ ), 51 conceptus were obtained from the five litters; of these, 36 were live fetuses $(70.6 \%)$, one dead fetus $(2 \%)$, and 14 reabsorptions $(27.4 \%)$, with an average of 7.2 live fetuses and 3.0 dead fetuses/reabsorptions per litter (Table I). In live fetuses external morphology was normal in $9(25 \%)$ and abnormal in $27(75 \%)$. The external morphological characteristics of the dead fetuses of this group were normal. 

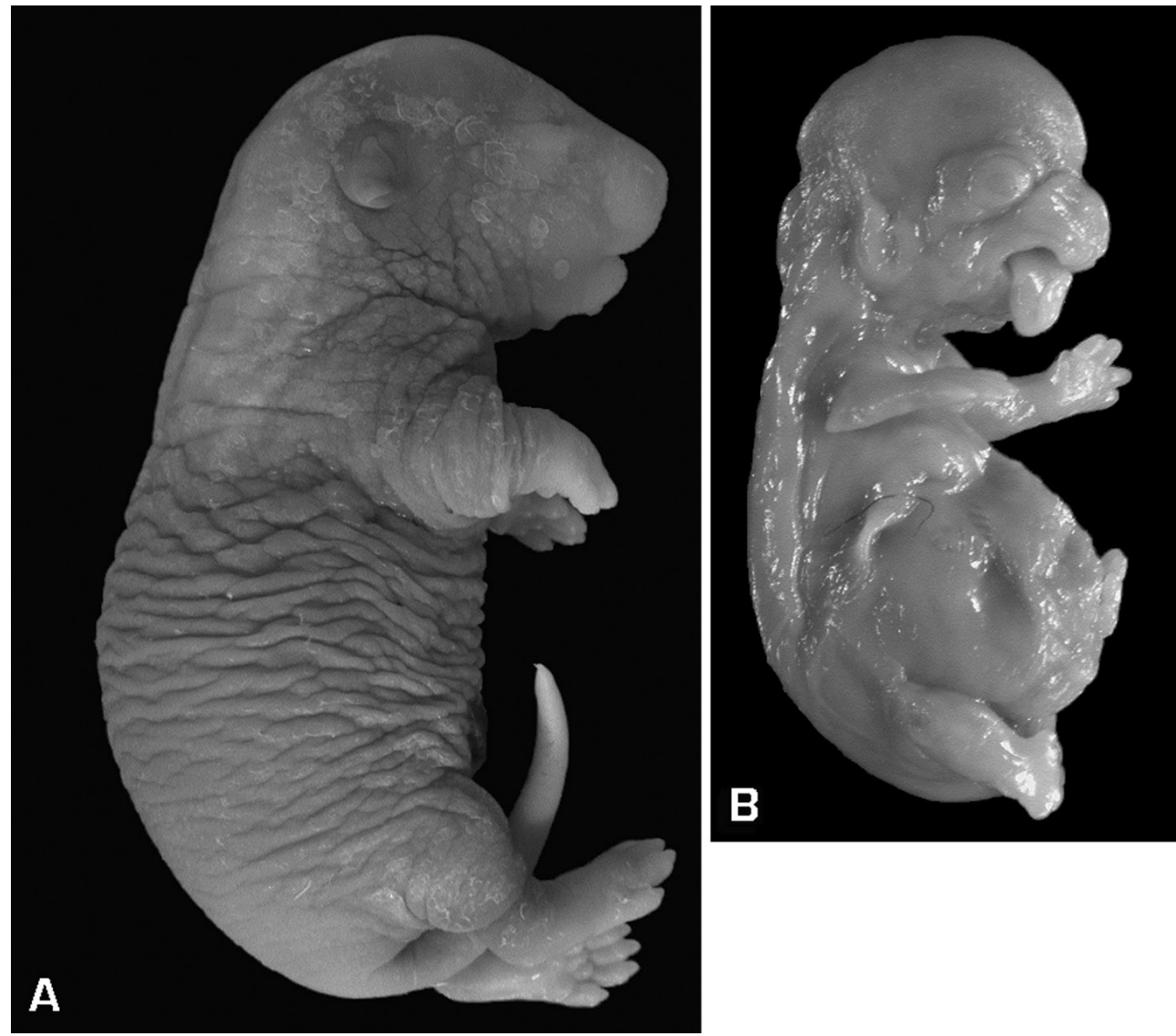

Fig. 1. Rat fetuses from different studied groups. A. Fetus from group A (control) revealing normal external characteristics on day 21 of gestation. B. Dead fetus from subgroup C3 (5\% mixture); note the abnormal morphology and the protruded tongue.
In subgroup $\mathrm{C}_{2}$ (solution at $2.5 \%$ ), 67 conceptus were obtained from the five litters; of these, 41 corresponded to live fetuses $(61.2 \%)$, one dead fetus $(1.5 \%)$, and 25 reabsorptions $(37.3 \%)$, with an average of 8.2 live fetuses and 5.2 dead fetuses/reabsorptions per litter (Table I). In live fetuses external morphology was normal in $2(4.9 \%)$ and abnormal in $39(95.1 \%)$. The external morphological characteristics of the dead fetus of this group were normal.

In subgroup $\mathrm{C}_{3}$ (solution at 5\%), 47 conceptus were obtained from the five litters; of these, only 17 were live fetuses $(36.2 \%)$, three dead fetuses $(6.4 \%)$, and 27 reabsorptions (57.4\%), with an average of 3.4 life fetuses and 6 dead fetuses/reabsorptions per litter (Table I). All the 17 live fetuses obtained showed abnormal morphology $(100 \%)$. From the three dead fetuses, two showed an abnormal morphology (Fig. 1B) and the last was a very early dead, in which it was not possible determine the normal or abnormal morphology.

Finally, in subgroups $\mathrm{C}_{4}$ (solution at 10\%) and subgroup $\mathrm{C}_{5}$ (solution at $20 \%$ ), no live or dead fetuses were obtained in any of litters, finding 62 and 46 reabsorptions, respectively, with an average of 12.4 and 9.2 reabsoptions

Table I. Conceptus, reabsorptions, dead and live fetuses.

\begin{tabular}{|c|c|c|c|c|c|c|c|}
\hline & $\begin{array}{c}\text { Group A: } \\
\text { Control }\end{array}$ & $\begin{array}{l}\text { Group B: } \\
\text { Saline } \\
\text { solution }\end{array}$ & $\begin{array}{c}\text { Group } \mathrm{C}_{1} \text { : } \\
1.25 \% \\
\text { mixture }\end{array}$ & $\begin{array}{c}\text { Group } \mathrm{C}_{2} \text { : } \\
2.5 \% \\
\text { mixture }\end{array}$ & $\begin{array}{c}\text { Group } \mathrm{C}_{3}: \\
5 \% \\
\text { mixture }\end{array}$ & $\begin{array}{c}\text { Group } \mathrm{C}_{4}: \\
10 \% \\
\text { mixture }\end{array}$ & $\begin{array}{c}\text { Group } \mathrm{C}_{5} \text { : } \\
20 \% \\
\text { mixture }\end{array}$ \\
\hline Number of conceptus & 61 & 63 & 51 & 67 & 47 & 62 & 46 \\
\hline Reabsorptions & $17(27.9 \%)$ & $10(15.8 \%)$ & $14(27.4 \%)$ & $25(37.3 \%)$ & $27(57.4 \%)$ & $62(100 \%)$ & $46(100 \%)$ \\
\hline Dead fetuses & 0 & $3(4.8 \%)$ & $1(2 \%)$ & $1(1.5 \%)$ & $3(6.4 \%)$ & 0 & 0 \\
\hline Live fetuses & $44(72.1 \%)$ & $50(79.4)$ & $36(70.6 \%)$ & $41(61.2 \%)$ & $17(36.2 \%)$ & 0 & 0 \\
\hline Number of live normal fetuses & 44 & 50 & 9 & 2 & 0 & 0 & 0 \\
\hline Number of live abnormal fetuses & 0 & 0 & 27 & 39 & 17 & 0 & 0 \\
\hline
\end{tabular}



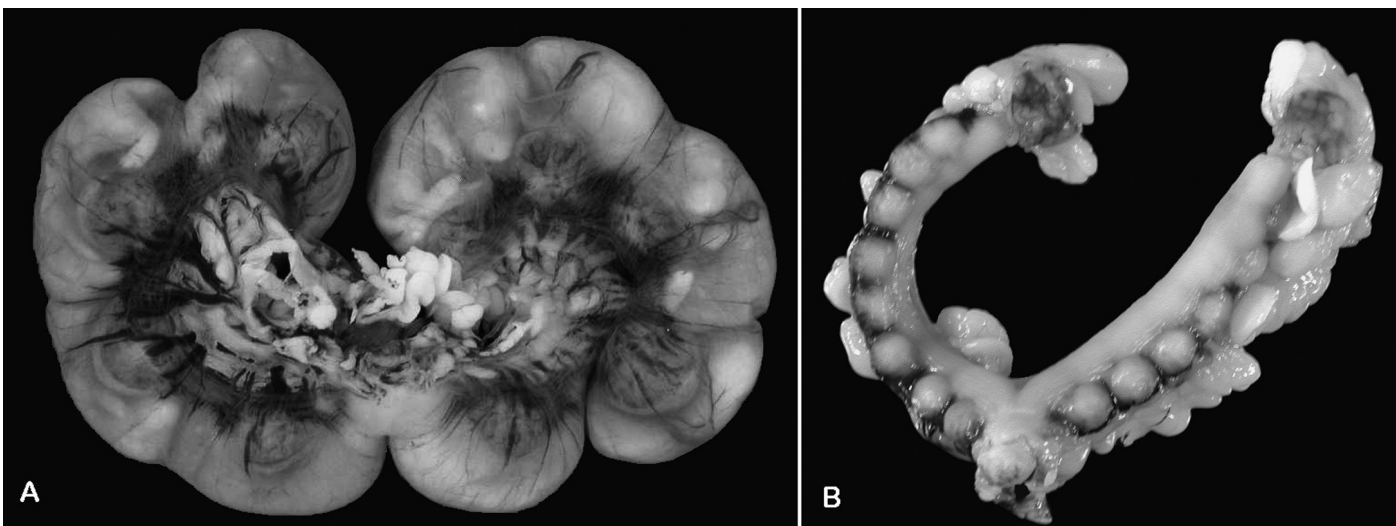

Fig. 2. Photographs of the whole uterine horns of two gestating rats from the study. A. Uterine horns of a group A (control) rat; note the increased volume of the horns, in which the fetuses can be appreciated by transparency. B. Uterine horns of a rat of subgroup C5; note only small heaps in both uterine horns, corresponding to the reabsorbed fetuses at an early stage.

per litter, respectively (Table I) (Fig. 2). From the size of the reabsorptions, these seemed to correspond to very early stages.

In the five groups in which fetuses were obtained (A, $\mathrm{B}, \mathrm{C}_{1}, \mathrm{C}_{2}$ and $\mathrm{C}_{3}$ ), no significant differences in the percentage of reabsoptions were found among groups $\mathrm{A}, \mathrm{B}, \mathrm{C}_{1}$ and $\mathrm{C}_{2}$, but between each of these and $\mathrm{C}_{3}$ the difference was statistically significant ( $p=0.02$ to $p<0.001)$. On the other hand, no differences were observed in the mortality rate among these five groups.

\section{DISCUSSION}

Several decades ago, the teratogenic principles were established and they can be summarized as follows: 1) susceptibility to teratogenesis depends on the genotype of the conceptus and the manner in which it interacts with environmental factors; 2 ) susceptibility to teratogenic agents varies with the developmental stage at the time of exposure; 3 ) teratogenic agents act in specific ways (mechanisms) on developing cells and tissues to initiate abnormal embryogenesis (pathogenesis); 4) the final manifestations of abnormal development are death, malformation, growth retardation, and functional disorder; 5) the access of adverse environmental influences to developing tissues depends on the nature of the influences (agent); and 6) manifestations of deviant development increase in degree as dosage increases from noeffect to totally lethal levels (Wilson, 1997).

Methyl cellosolve is considered, within the group of glycol ethers, as the most powerful teratogenic agent (Nelson et al., 1984a), existing reports on different mechanisms by which it exerts its action on different biological models: inhibition of ornithin decarboxilase (Toraason \& Breitenstein, 1988), increase of intracellular $\mathrm{pH}$ (Nelson et al., 1989), limbs necrosis (Greene et al., 1987), apoptosis of the neural epithelium and neural crests (Ambroso et al., 1998), interaction with membrane proteins (Lee et al., 1993), inhibition of the gap junctions (Welsch \& Stedman, 1984), and alterations in the concentration of neurotransmitters (Nelson et al., 1984b). In humans, it has been reported that this substance produces chromosomal damage in children of exposed mothers (El-Zein et al.) and that it acts through its metabolite, methoxyacetic acid (Ritter et al., 1985), which has a long life and accumulates in maternal sera and uniformly in all embryonic tissues (Scott et al., 1989).

Regarding ethylene glycol, also of the group of glycol ethers, the teratogenic mechanism by which it exerts its actions is still unknown, but it is known that the glycolic acid is its main metabolite with teratogenic action (Carney et al., 1999; Munley et al., 1999).

Potentiation in vitro of the effect of methyl cellosolve by ethylene glycol has been reported in cells in culture that were exposed to a mixture of these substances, apparently through the inhibition of the gap junctions (Vitek, 1993) or by the action of two or more metabolites with teratogenic capacity, which act through multiple mechanisms. This is important, since in industry it is frequent to use them combined, as was the case of the mothers of the patients of the Mexican border city (Saavedra-Ontiveros et al.; Saavedra et al., 1997).

The reabsorption of the conceptus in the rat results from embryonic death in early stages, with the consequent disorganization of the intra- and extra-embryonic tissues, and encapsulation of tissue remnants; usually, this process happens in approximately 10 to $20 \%$ of the embryos at the beginning 
of their development, as was observed in our group A (control) in which $15.9 \%$ of reabsorptions occurred. In subgroups $\mathrm{C}_{4}$ and $\mathrm{C}_{5}$ (mixture of solvents at 10 and $20 \%$ ), all the rats presented $100 \%$ of reabsorptions (Fig. 2), as well as one rat of subgroup C3 (mixture at 5\%), which reveals the severity of the combined action of these agents at these concentrations, killing the embryo at very early stages. In our previous research, $100 \%$ of reabsorptions occurred only in three of the five rats tested with methyl cellosolve at $20 \%$, whereas this was neither observed with smaller dilutions of this substance, nor with any of the ethylene glycol dilutions (SaavedraOntiveros et al.; Saavedra et al., 1997). Complete reabsorptions can take place in rats exposed to inhalation of methyl cellosolve (Nelson et al., 1984a). Our present findings evidenced that the combination of both solvents produces more mortality in embryos than when applied separately.
Fetal death is also a phenomenon of loss of gestation but, in this case, death occurs in late developmental stages, not giving time for the disorganization and encapsulation of fetal tissues. In our experimental subgroups, no significant increase in fetal deaths occurred indicating that the mixture of these teratogenic agents did not produce late fetal death.

Our results allow us to conclude that chronic exposure of gestating rats to the ethylene glycol-methyl cellosolve mixture has a more powerful teratogenic effect than when they act separately, producing an evident reproductive damage. These findings are very relevant since, in the working environment, it is very frequent to use these chemicals combined and even with other solvents, therefore they pose a greater risk of developmental alterations than those reported when used alone.

ARTEAGA-MARTÍNEZ, M.; GARCÍA-PELÁEZ, I.; AGUIRRE-LUNA, O. M. \& SAAVEDRA-ONTIVEROS, D. Teratogénesis por etilenglicol-metilcelosolve en ratas. I. Daño reproductivo. Int. J. Morphol., 28(4):1087-1092, 2010.

RESUMEN: Se investigó el daño reproductivo y efecto teratogénico de una mezcla de etilenglicol y metilcelosolve en ratas gestantes, las cuales recibieron por vía intraperitoneal una dosis diaria, a diferentes concentraciones de la mezcla, del día 8 al día 20 de gestación. En las ratas tratadas con la mezcla el número de fetos vivos disminuyó y las reabsorciones y el número de fetos anormales aumentaron a mayor concentración de los solventes. Concluimos que la mezcla de etilenglicol-metilcelosolve tiene mayor efecto teratogénico que cuando actúan cada uno de los solventes por separado, produciendo daño reproductivo, anormalidades fetales externas, retraso del crecimiento y aumento de muerte fetal.

\section{PALABRAS CLAVE: Etilenglicol; Éter de glicol; Metilcelosolve; Fetos de rata; Teratogénesis.}

\section{REFERENCES}

Ambroso, J. L.; Stedman, D. B.; Elswick, B. A. \& Welsch, F. Characterization of cell death induced by 2methoxyethanol in CD-1 mouse embryos on gestation day 8. Teratology, 58(6):231-40, 1998.

Anderson, L. S. Panel discussion of the 3rd International Scientific Symposium of the Health Effects of Glycol Ethers. Toxicol. Lett., 156(1):217-25, 2005.

Bolt, H. M. \& Golka, K. Maternal exposure to ethylene glycol monomethyl ether acetate and hypospadia in offspring: a case report. Br. J. Ind. Med., 47(5):352-3, 1990.

Carney, E. W.; Freshour, N. L.; Dittenber, D. A. \& Dryzga, M. D. Ethylene glycol developmental toxicity: unraveling the roles of glycolic acid and metabolic acidosis. Toxicol. Sci., 50(1):117-26, 1999.

Cook, R. R.; Bodner, K. M.; Kolesar, R. C.; Uhlmann, C. S.; VanPeenen, P. F.; Dickson, G. S. \& Flanagan, K. A. Crosssectional study of ethylene glycol monomethyl ether process employees. Arch. Environ. Health, 37(6):346-51, 1982.
Cordier, S.; Bergeret, A.; Goujard, J.; Ha, M. C.; Ayme, S.; Bianchi, F.; Calzolari, E.; De Walle, H. E.; Knill-Jones, R.; Candela, S.; Dale, I.; Dananche, B.; de Vigan, C.; Fevotte, J.; Kiel, G. \& Mandereau, L. Congenital malformation and maternal occupational exposure to glycol ethers. Occupational Exposure and Congenital Malformations Working Group. Epidemiology, 8(4):355-63, 1997.

Dieter, M. NTP technical report on the toxicity studies of ethylene glycol ethers: 2-methoxyethanol, 2-ethoxyethanol, 2butoxyethanol (CAS Nos. 109-86-4, 110-80-5, 111-76-2) administered in drinking water to $\mathrm{F} 344 / \mathrm{N}$ rats and B6C3F1 mice. Toxic. Rep. Ser., 26:1-G15, 1993.

El-Zein, R. A.; Abdel-Rahman, S. Z.; Morris, D. L. \& Legator MS. Exposure to ethylene glycol monomethyl ether: clinical and cytogenetic findings. Arch. Environ. Health, 57(4):371-6, 2002.

Greene, J. A.; Sleet, R. B.; Morgan, K. T. \& Welsch, F. Cytotoxic effects of ethylene glycol monomethyl ether in the forelimb bud of the mouse embryo. Teratology, 36(1):23-4, 1987.

Horton, V. L.; Sleet, R. B.; John-Green, J. A. \& Welsch, F. Developmental phase-specific and dose-related teratogenic effects of ethylene glycol monomethyl ether in CD-1 mice. Toxicol. Appl. Phamacol., 80(1):108-18, 1985. 
Johanson, G. Toxicity review of ethylene glycol monomethyl ether and its acetate ester. Crit. Rev. Toxicol., 30(3):307-45, 2000.

Karaman, M. I.; Gurdal, M.; Ozturk, M. \& Kanberoglu, H. Maternal exposure to diethylene glycol monomethyl ether: a possible role in the etiology of retrocaval ureter. J. Pediatr. Surg., 37(8):E23, 2002 .

Lee, J.; Trad, C. H. \& Butterfield, D. A. Electron paramagnetic resonance studies of the effects of methoxyacetic acid, a teratologic toxin, on human erythrocyte membranes. Toxicology 83(1-3):131-48, 1993.

Munley, S. M.; Kennedy, G. L. \& Hurtt, M. E. Developmental toxicity study of glycolic acid in rats. Drug Chem. Toxicol., 22(4):56982, 1999.

Nelson, B. K.; Setzer, J. V.; Brightwell, W. S.; Mathinos, P. R.; Kuczuk, M. H.; Weaver, T. E. \& Goad, P. T. Comparative inhalation teratogenicity of four glycol ether solvents and an amino derivative in rats. Environ. Health Perspect., 57:261-71, 1984a.

Nelson, B. K. \& Brightwell, W. S. Behavioral teratology of ethylene glycol monomethyl and monoethyl ethers. Environ. Health Perspect., 57:43-6, 1984b.

Nelson, B. K.; Vorhees, C. V.; Scott, W. J. Jr. \& Hastings, L. Effects of 2-methoxyethanol on fetal development, postnatal behavior, and embryonic intracellular $\mathrm{pH}$ of rats. Neurotoxicol. Teratol., 11(3):273-84, 1989.

Oudiz, D. J.; Walsh, K. \& Wiley, L. M. Ethylene glycol monomethyl ether (EGME) exposure of male mice produces a decrease in cell proliferation of preimplantation embryos. Reprod. Toxicol., 7(2):101-9, 1993.

Pastides, H.; Calabrese, E. J.; Hosmer, D. W. Jr. \& Harris, D. R. Jr. Spontaneous abortion and general illness symptoms among semiconductor manufacturers. J. Occup. Med., 30(7):543-51, 1988.

Ritter, E. J.; Scott, W. J. Jr.; Randall, J. L. \& Ritter, J. M. Teratogenicity of dimethoxyethyl phthalate and its metabolites methoxyethanol and methoxyacetic acid in the rat. Teratology, 32(1):25-31, 1985.

Saavedra-Ontiveros, D.; Arteaga-Martínez, M.; Serrano-Medina, B.; Reynoso-Arizmendi, F.; Prada-Garay, N. \& Cornejo-Roldán, L. R. Contaminación industrial con solventes orgánicos como causa de teratogénesis. Sal. Pub. Mex., 38:3-12, 1996.

Saavedra, D.; Arteaga, M. \& Tena, M. Industrial contamination with glycol ethers resulting in teratogenic damage. Ann. NY Acad. Sci., 837:126-37, 1997.

Saavedra, D.; Tena, M.; Cornejo, L. R.; Servín, L. M. \& Arteaga, M. Alteraciones craneofaciales y del sistema nervioso central producidas por solventes orgánicos. Estudio experimental en ratas. Rev. Hosp. Gral. Dr. M. Gea González, 1(1):8-15, 1998.
Scott, W. J.; Fradkin, R.; Wittfoht, W. \& Nau, H. Teratologic potential of 2-methoxyethanol and transplacental distribution of its metabolite, 2-methoxyacetic acid, in non-human primates. Teratology, 39(4):363-73, 1989.

Smith, R. L. Review of glycol ether and glycol ether ester solvents used in the coating industry. Environ. Health Perspect., 57:1-4, 1984.

Swan, S. H.; Beaumont, J. J.; Hammond, S. K.; VonBehren, J.; Green, R. S.; Hallock, M. F.; Woskie, S. R.; Hines, C. J. \& Schenker, M. B. Historical cohort study of spontaneous abortion among fabrication workers in the semiconductor health study: agentlevel analysis. Am. J. Ind. Med. 28(6):751-69, 1995.

Terry, K. K.; Elswick, B. A.; Stedman, D. B. \& Welsch, F. Developmental phase alters dosimetry-teratogenicity relationship for 2-methoxyethanol in CD-1 mice. Teratology, 49(3):218-27, 1994.

Toraason, M. \& Breitenstein, M. Prenatal ethylene glycol monomethyl ether (EGME) exposure produces electrocardiographic changes in the rat. Toxicol. Appl. Pharmacol., 95(2):321-7, 1988.

Vachhrajani, K. D. \& Dutta, K. K. Stage specific effect during one seminiferous epithelial cycle following ethylene glycol monomethyl ether exposure in rats. Indian J. Exp. Biol., 30(10):892-6, 1992.

Vitek, J. A. Inhibition of intercellular gap junctional communication by alkyl ethers and its modulation by cAMP. Neoplasma, 40(3):167-72, 1993.

Welsch, F. \& Stedman, D. B. Inhibition of intercellular communication between normal human embryonal palatal mesenchyme cells by teratogenic glycol ethers. Environ. Health Perspect., 57:125-33, 1984.

Wilson, J. G. Current status of teratology. General principles and mechanisms derived from animal studies. In: Wilson, J. G. \& Fraser, F. C. (Eds). Handbook of Teratology. New York, Plenum Press, 1997. pp.47-74.

\section{Correspondence to:}

Dr. Manuel Arteaga-Martínez

Jefe del Departamento de Anatomía

Facultad de Medicina UNAM

Ciudad Universitaria,

O4510-México, D.F.

Tel.: (+52-55) 56-23-24-23

Fax: (+52-55) 56-23-24-25

Email: manuelarteagamartinez@hotmail.com smam48@gmail.com

Received: 21-07-2010

Accepted: 29-09-2010 